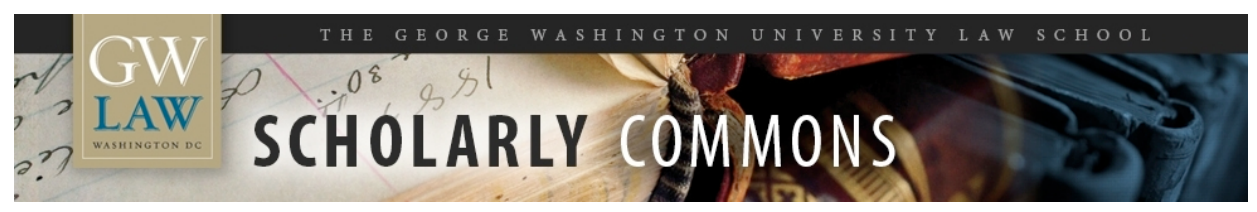

\title{
How Do We Know When an Enterprise Exists? Unanswerable Questions and Legal Polycentricity in China
}

Donald C. Clarke

George Washington University Law School, dclarke@law.gwu.edu

Follow this and additional works at: https://scholarship.law.gwu.edu/faculty_publications

Part of the Law Commons

\section{Recommended Citation}

19 Colum. J. Asian L. 50 (2005)

This Article is brought to you for free and open access by the Faculty Scholarship at Scholarly Commons. It has been accepted for inclusion in GW Law Faculty Publications \& Other Works by an authorized administrator of Scholarly Commons. For more information, please contact spagel@law.gwu.edu. 


\title{
HOW DO WE KNOW WHEN AN ENTERPRISE EXISTS? \\ UNANSWERABLE QUESTIONS AND LEGAL POLYCENTRICITY IN CHINA
}

\author{
DONALD C. ClaRkE*
}

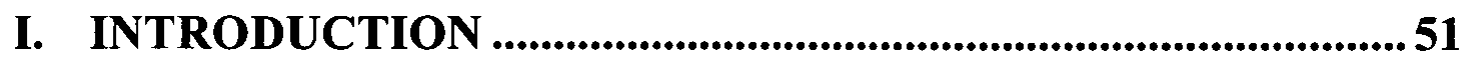

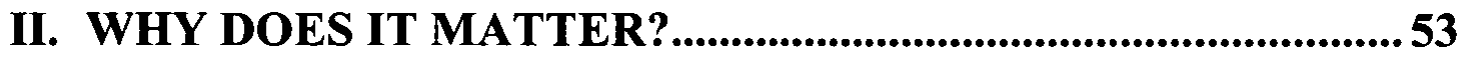

III. NON-STATUTORY ENTERPRISES IN CHINA ....................55

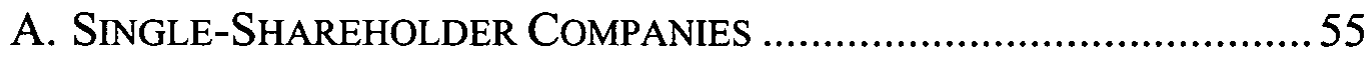

B. SHAREHOLDING COOPERATIVE ENTERPRISES .............................57

C. LIMITED LIABILITY PARTNERSHIPS ............................................59

D. Limited Liability COMPANIES AND JOINT STOCK COMPANIES ...61

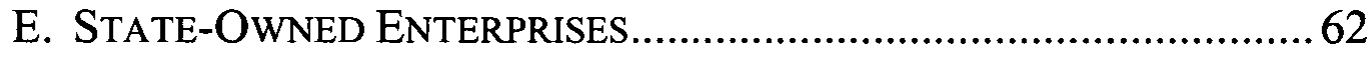

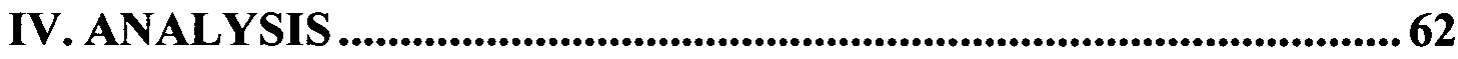

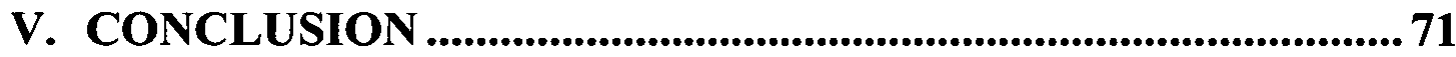

"Professor, George Washington University Law School. 
[A] corporation ... exists only in contemplation of law, and by force of the law; and where that law ceases to operate, and is no longer obligatory, the corporation can have no existence. ${ }^{1}$

Where the law has not made provisions about other forms of companies, this by no means implies that they cannot be established; exploration may be carried out in the course of practice.... ${ }^{2}$

\section{INTRODUCTION}

One of the most perplexing aspects of Chinese enterprise law ${ }^{3}$ concerns the conditions under which state institutions will acknowledge and give effect to the existence of a business organization distinct from the natural or legal persons that participate in its operations. The answer might appear to be simple - they will do so whenever legally stipulated conditions are met-but this answer would be wrong. State institutions often give real and meaningful effect to the existence of entities with no apparent statutory basis, or whose legal basis dictates consequences that seem at odds with the consequences called for by constitutionally superior law.

There can be no simple answer to the question of whether a business organization exists or not. Existence cannot be determined in the abstract. The answer must depend on the problem to be solved. For example, if the law requires a count of residents in a district, corporations do not exist at all. They are invisible to the law. But if the law requires a count of taxpayers, they suddenly reappear in front of the eyes of the state. We are accustomed to thinking of corporations and other business organizations as objectively existing because they are deemed to exist for many purposes. But it should be clear that there are many situations in which they do not exist-or at least, situations in which, like a ghost, they do not meaningfully interact with the world, in which case the question of whether they actually "exist" or not is metaphysical and uninteresting.

\footnotetext{
${ }^{1}$ Bank of Augusta v. Earle, 38 U.S. 519, 588 (1839).

2 市耀武，关于对“中华人民共和国公司法(草案)”的意见的汇报 [Bian Yaowu, Report on Opinions Concerning the “Company Law of the People's Republic of China (Draft)'], June 22, 1993, in 12/1993 中华人民共和国人民代表大会常务委员会公报 [STANDING COMM. NAT'L PEOPLE'S CONG. GAZ.] 51-60.

${ }^{3}$ By "enterprise law" I mean the body of rules, regulations, and norms governing the organization and operation of business entities purporting to any kind of existence distinct from that of the legal or natural persons that participate in the business. Thus, I include partnership law where it exists, whether or not it deems partnerships to be separate legal persons with limited liability, but exclude for current purposes organizations such as political parties.
} 
But people make claims in the real world that business organizations exist because they want certain consequences to follow from a recognition of that existence, and those to whom the claims are made-very often, courts and administrative agencies-must decide whether the claim is true. They must decide whether to recognize the asserted existence of the entity. For example, when a creditor sues me for a debt, I may try to escape liability by pleading that the debt belongs to a corporation of which I am merely a shareholder. ${ }^{4}$ The creditor, of course, may try to argue that in fact the debt belongs to a partnership of which I am a partner, and that I am therefore liable. If I claim that a corporation exists, the court must have some way of deciding whether my claim is true. How does it do so? On what basis does the court (or some other government agency) decide that a corporation does or does not exist?

It is this question in the Chinese enterprise law context that I want to raise in this essay. I have asserted above, and shall demonstrate below, that Chinese courts and government agencies do not consider a statute to be necessary for the recognition of an organization's existence. ${ }^{5}$ At the same time, however, it is unlikely that mere assertion by an interested party is good enough, either. But if a legal basis is not required, what exactly is the basis of a governmental decision that an entity exists or not?

It is not the objective of this essay to come up with a definitive answer, although I have some speculations at the end. More research into specific cases is needed. What I want to do here is simply to raise this as an issue, because to the best of my knowledge it has not been explored. ${ }^{6}$ One question to examine, of course, is why it has not been explored. Why has this question generally not been considered important or interesting? Or

\footnotetext{
${ }^{4}$ In one anomalous case, the shareholder urged that the existence of the corporate debtor be ignored; this would have turned a farm owned by the corporation into one owned by the shareholder, and thus shielded from creditors pursuant to a homestead exemption available in bankruptcy to individuals. See Cargill, Inc. v. Hedge, 375 N.W.2d 477 (Minn. 1985).

${ }^{5}$ See, for example, the quotation from Bian Yaowu, the deputy head of the Legislative Affairs Commission of the Standing Committee of the National People's Congress, in Bian, supra note 2.

${ }^{6}$ Professor Jiang Ping has raised a similar, although not identical, issue with his conception of "企业 法定主意" (qiye fading zhuyi), an adaptation of the Chinese term for "nullem crimen sine lege" that might be roughly translated as "no enterprise without a law providing for it"). See, e.g., 江平, 公司 法与上市企业的改革与完善(二)[Jiang Ping, The Reform and Perfection of Commercial Enterprises and the Company Law (Part 2)], 中国律师 (THE ChINESE LAWYER), No. 2, 1999, at 55-57. His concerns are similar, in that he is concerned by the problems posed by the existence of business organizations without any apparent legal basis. His conception of the issue is slightly different, I believe, in that I read him as viewing the establishment of enterprises without a legal basis as something that can but should not happen, whereas I am interested in exploring why it is not simply a legal impossibility. After all, we do not tell people that they may not or ought not to transfer ownership of their car to the family dog. The law simply does not recognize animals as property owners, and no state body will recognize the purported assignment.
} 
why has the answer, in any individual case, always been considered self-evident?

The remainder of this essay will discuss in Part II why the issue of the legal basis for enterprise existence is an interesting and important question in Chinese law. Part III will examine the reality on the ground in China, and give examples of the many different types of enterprise organization that seem to obtain some degree of official recognition, at least for some purposes, despite their lack of statutory basis. Part IV, the theoretical part of this essay, analyzes the phenomena canvassed in previous sections. Part V contains the conclusion.

\section{WHY DOES IT MATTER?}

We can understand the importance of the central question of this essay by thinking about what it means for the existence of a business organization to be recognized by a state agency. As noted above, the question of whether an organization's existence should be recognized cannot be answered in the abstract; it all depends on the problem before the decision-maker that needs to be solved. What might these problems be?

One obvious problem concerns the liability of participants in the organization to third parties. Suppose there are investors who purport to have created a limited liability organization and to have done business through it, and suppose further that the business ${ }^{7}$ has not generated enough money to pay its debts. Creditors will seek to make the investors liable; investors, for their part, will seek to interpose the limited liability organization as a shield, and deny their own personal liability. In the face of these conflicting claims, it seems clear that a court could not find for the defendants on the basis of nothing more than their assertion that the business had been conducted through a limited liability organization. There must be some basis outside of the investors' claims for deciding upon their validity. And the legal basis of those claims is particularly important. After all, the claims of the creditors may, in China, be grounded in national law-specifically, the General Principles of Civil Law or the Contract Law-and therefore any denial of this liability must be grounded in a norm of constitutionally equal or superior status. If that norm is the Company Law, which explicitly provides for limited liability, there is no difficulty. But if the purported limited liability organization is not a creature of the Company Law, then some other basis is necessary for

\footnotetext{
${ }^{7}$ I use the vague term "the business" deliberately in order to avoid prejudging the question of whether
} the business should be deemed to have been carried on by individuals or by an organization. 
deciding whether or not to accept the investors' claims. In this context, then, to recognize a business organization's existence means to accept investors' claims that they are not liable to third party creditors. This decision needs to be justified.

Another set of problems relates to matters of internal corporate governance. A successful business creates a large pool of assets over which participants may engage in a struggle for control. At the most basic level, there can be disputes over who has the right to speak for the organization and make dispositions of its assets. There may also be disputes over how to divide profits or remaining assets upon liquidation. To recognize the organization as an organization of statutory type $X$ means to use the rules of internal corporate governance-for example, allocating voting rights in accordance proportionate to amount of capital invested instead of using the one-investor-one-vote principle - that apply to type- $X$ organizations. Not to recognize it means that there is no statutory source for internal governance rules, and the source of those rules must be sought elsewhere-perhaps in an agreement (express or more probably implied) among the participants. In this case, to recognize a business organization's existence necessarily means to characterize it as an organization of a certain type, and thereby to accept a claim that one particular set of governance rules, and not another, should apply when resolving disputes among voluntary participants in the business.

Because the decision as to whether or not an organization "exists" can have important real-world consequences in particular situations, courts and other decision-makers must have some standard according to which to make their decision if the decision-making process can be called a "legal" one in the usual sense of the word. Clearly, the bald assertion that an organization exists cannot be enough. When we say that an organization exists, that must mean that its existence is acknowledged by others in important and meaningful ways. It is important to state this point clearly: no person or group of persons can successfully establish a legally recognized organization on their own unless the legal system cooperates by acknowledging and recognizing what they have done. Indeed, the question of whether an organization "exists" or not is unimportant; the question is whether it can interact with the world, and whether its alleged existence makes any difference in the world. The answer to that question lies in whether its existence is acknowledged. Therefore, the question when we see a claim that an entity exists is not why the organizers established it (even when there may be no law providing for such an organization, or indeed where they may be a law forbidding such an organization). The question is why other people and organizations, including state 
organizations, do or should give recognition to this entity even where it has no legal basis.

\section{NON-STATUTORY ENTERPRISES IN CHINA}

There can be no doubt that courts and government agencies in China do grant de facto recognition to business organizations and other entities that have no solid statutory basis. By "solid statutory basis" I mean a basis in law that can, consistent with China's constitutional order, explain why certain legal consequences follow from an acknowledgment of the organization's existence. Thus, for example, I consider a joint stock company established in accordance with the rules of the Company Law to have a solid statutory basis, since the Company Law was passed by the National People's Congress Standing Committee, and the rights and duties established under that law do not contradict those of any higher law (the only higher law being the Constitution). As I shall show, however, other entities do not have a similarly solid basis. The following discussion identifies a few of the more prominent examples.

\section{A. $\quad$ Single-Shareholder Companies}

Chinese statutory law currently disfavors single-shareholder companies. The Company Law currently ${ }^{8}$ allows for three types of companies: ordinary limited liability companies (“LLCs”) (有限责任公司, youxian zeren gongsi), which must have at least two founders and initial shareholders, 9 wholly state-owned limited liability companies ("WSOLLCs"), which may have a single founder and shareholder if that shareholder is a government agency, ${ }^{10}$ and joint stock companies ("JSCs") (股份有限公司, gufen youxian gongsi), which must have at least five founders and initial shareholders. " Unlike Chinese nationals, foreign companies and individuals may establish solely-owned companies under

\footnotetext{
${ }^{8}$ This essay was written too late to take account of recent revisions in the Company Law that took effect on Jan. 1, 2006. All references herein to the Company Law refer to the version in effect prior to that date.

9 中华人民共和国公司法 [Company Law] art. 20 (promulgated by the Standing Comm. of the Nat'l People's Cong., Dec. 29, 1993, effective July 1, 1994, as amended through Aug. 28, 2004) (P.R.C.), available at http://www.chinalawedu.com/news/2004\%5C11\%5Czh725359301821140021520.html (last visited Feb. 20, 2006) [hereinafter Company Law].

${ }^{10}$ Id. at art. 64.

${ }^{11}$ Id. at art. 75. There is an exception for JSCs founded through the conversion of state-owned enterprises: these may have fewer than five promoters. But they must be established through public offer-in other words, additional shareholders must be brought in at the time of establishment.
} 
the Law on Wholly Foreign-Owned Enterprises. ${ }^{12}$ There was considerable controversy over the issue of single-shareholder companies during the drafting of the Company Law. In one of the original drafts, companies solely owned by legal persons were allowed, but the section was later removed. ${ }^{13}$ This indicates that sole ownership was not overlooked; on the contrary, it was considered and rejected. ${ }^{14}$

Despite its strict rules on the establishment of companies, the Company Law nowhere actually prohibits the continued existence of a LLC or JSC where all the shares have come under the ownership of a single shareholder, or provides for any consequences to follow such an event. ${ }^{15}$ Thus, single-shareholder companies seem to be possible although not simple to establish. A promoter could establish a company with several nominal shareholders, and those shareholders would simply transfer their interests to the promoter after the expiration of any holding period required by law (in the case of JSCs, for example, three years). ${ }^{16}$

Whatever the rules of the Company Law may be, many business entities do in fact establish subordinate entities that purport to be wholly owned subsidiaries and are described as such. The subsidiaries are apparently not, however, formed through the method I have described

12 中华人民共和国外资企业法 [Law on Wholly Foreign-Owned Enterprises] (promulgated by the Standing Comm. of the Nat'l People's Cong., Oct. 31, 2000, effective Oct. 31, 2000) 11/2000 全国 人民代表大会常务委员会公报 [STANDING COMM. NAT'L PEOPLE'S CONG. GAZ.] 652 (P.R.C.), available at $\mathrm{http}: / / \mathrm{www} .00615$.net/waizi/wf/w_12.htm (last visited Feb. 20, 2006).

${ }^{13}$ See 江平, 公司法从19世纪到20世纪的发展 [Jiang Ping, The Development of Company Law from the 19th Century to the 20th Century], in 公司法修改纵横谈 [GENERAL DISCUSSION OF REVISION OF THE COMPANY LAW] 21, 24 (郭峰 \& 王坚编 [Guo Feng \& Wang Jian eds.], 2000) [hereinafter GENERAL DISCUSSION OF REVISION OF THE COMPANY LAW].

${ }^{14}$ It is hard to know where exactly the objections lie, but they seem to center around concern for creditors. According to one commentator, legislators were concerned that company promoters might falsify the value of their capital contributions, thus giving the company a high initial book value. Requiring more than one promoter would, it was thought, mean that each would monitor the others and prevent false reporting. See Jiang, supra note 13, at 25 . It is hard to see how requiring more than one promoter would solve this problem, since the promoters could easily collude to overstate the value of their capital contributions by the same multiple. Furthermore, the entire creditor-protection rationale depends, as far as voluntary creditors are concerned, upon the assumption that voluntary creditors rely on the book value of the initial capitalization-an event that may have happened years before-when deciding whether to extend credit, instead of the actual value of a firm's current assets or its future earnings. If Chinese lenders are indeed this obtuse, then the crisis in the banking system is easily explained. Still less do involuntary creditors such as tort victims rely on initial capitalization at the time the tort is committed. In addition, were Chinese company law to discard initial capitalization requirements, this argument against single-shareholder companies would lose whatever force it might have.

${ }^{15}$ See 马传刚, 从一人公司的现状看公司法的修改 [Ma Chuan'gang, Viewing Revision of the Company Law from the Current Situation Regarding Single-Person Companies], in GENERAL DISCUSSION OF REVISION OF THE COMPANY LAW, supra note 13, at 142-43.

${ }^{16}$ This interpretation is confirmed in 施天涛, 商法学 [SHI TIANTAO, COMMERCIAL LAW] 136-37 (2004). 
above, but are solely owned from the very start. ${ }^{17} \mathrm{~A}$ business organization that has a single corporate shareholder from the very start cannot be a company under the Company Law; ${ }^{18}$ but if it is not a company under the Company Law, what is it? I know of no other enterprise organizational statute that might cover such an organization.

Despite this lack of statutory basis, not only courts, but creditors as well seem to accept the existence of single-shareholder subsidiaries, even when it would be in their interest to insist that the so-called subsidiary has no legal existence and should be invisible to the court (thus allowing the creditors to reach the assets of the parent). In one reported case, while creditors indeed attempted (unsuccessfully) to pierce the corporate veil of the subsidiary, nobody involved appears to have considered the argument that there was not, legally speaking, any veil there in the first place. ${ }^{19}$

\section{B. $\quad$ Shareholding Cooperative Enterprises}

Organizations calling themselves shareholding cooperative enterprises (“SCEs”) (股份合作制企业, gufen hezuozhi qiye) have been in existence since the mid-1980s, ${ }^{20}$ and the first regulation governing them seems to have been issued by the Wenzhou City government in $1987 .^{21}$

\footnotetext{
${ }^{17}$ Examples can easily be found by searching Chinese news databases using such terms as quanzi zigongsi (全资子公司, wholly-owned subsidiary). See, for example, the announcement by listed company 中华国际 (China International) of its intention to inject more capital into Hainan Zhonghua Shipping Enterprise Company, described as a wholly-owned subsidiary that is a company. See 上市 公司信息 [Listed Company Information], 重庆晚报 [CHONGQING EVENING NEWS] (Sept. 4, 2002), available at $\mathrm{http}: / / \mathrm{www} . c h i n a i n f o b a n k . c o m$. The State Council itself recently approved the establishment of wholly-owned subsidiaries under the China Airlines Group Company. See 国务院, 关于组建中国航空集团公司有关问题的批复 [State Council, Approval Reply Concerning Issues Related to the Establishment of the China Airlines Group Company] (July 14, 2002), available at http://www.chinainfobank.com.

${ }^{18}$ The Company Law does provide in Article 13 that companies may establish subsidiaries and that such subsidiaries shall have separate legal personality, but it is hard to read this single sentence as an authorization for a new type of company not otherwise provided for in the Company Law (i.e., a WSOLLC, an LLC, or a JSC), especially as nothing else is said about the governance rules for such a company and we know from the legislative history of the Company Law that companies with a single legal-person shareholder were explicitly considered and rejected.

${ }^{19} \mathrm{See}$ 黄学海 \& 王少春, 企业法公司法案利精选精析 [HUANG XUEHAI \& WANG SHAOCHUN, SELECTED CASES AND ANALYSES IN ENTERPRISE LAW AND COMPANY LAW] 32-36 (1998).

${ }^{20}$ See 乡镇企业的发展要讲求效益, 目前主要问题是发展速度过快需要引导 [The Development of Township and Village Enterprises Should Stress Efficiency: At Present the Main Problem Is that the Speed of Development Is Too Fast and Guidance Is Needed], 经济日报 [ECON. DAILY] (June 10,

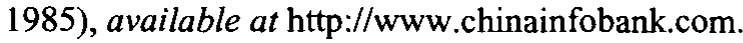

${ }^{21}$ Wenzhou City Government, 关于农村股份合作企业若干问题的暂行规定 [Provisional Rules on Several Issues Concerning Rural Shareholding Cooperative Enterprises] (Nov. 1987). I have found only references to this document, see, e.g., http://www.wznw.gov.cn/jsdd/wzncl.htm, a Wenzhou City government website, and have not personally seen a copy of the actual text.
} 
The earliest regulation purporting to govern entities with that name of which I have seen the text is one issued by the Liaoning Provincial Government (not the Provincial People's Congress) in January of $1990 .^{22}$ This document, however, clearly contemplates that SCEs are already in existence, since it seems to refer to an already well-known organizational form. Nevertheless, it does spell out some internal governance rules, and implies (without actually directly saying so) that the SCE has limited liability, and that creditors cannot look beyond the SCE for repayment. ${ }^{23}$

There do not appear to have been any national-level rules about SCEs until the following month, when the Ministry of Agriculture issued its Provisional Rules on Farmers' Shareholding Cooperative Enterprises. ${ }^{24}$ These rules specifically state that a properly organized SCE shall be a legal person, ${ }^{25}$ with the attendant implication of limited liability.

The earliest regulations on urban SCEs of which I can find the entire text are the Experimental Provisions on the Shareholding Cooperative System for Collective Enterprises in Light Industry, issued in 1993 by the All-China Union of Light Industry (全国轻工总会, Quanguo Qing Gong Zonghui). ${ }^{26}$ These regulations also stipulate that the covered SCEs have limited liability.

Finally, the highest governmental body that seems to have addressed the issue of SCEs is the State Commission on Reform of the Economic System ("SCRES"), which in 1997 issued a Guidance Opinion on the Development of Urban Shareholding Cooperative Enterprises. ${ }^{27}$ This opinion, like the other documents and regulations cited above, states

\footnotetext{
${ }^{22}$ The regulations in question are called the Provisional Measures of Liaoning Province on the Implementation of the Shareholding Cooperative System by Urban Collectively-Owned Enterprises (the “Liaoning SCE Measures"). See Liaoning Provincial Government, 辽宁省城镇集体所有制企 业实行股份合作制暂行办法 [Provisional Measures of Liaoning Province on the Implementation of the Shareholding Cooperative System by Urban Collectively-Owned Enterprises] (Jan. 1, 1990), available at $\mathrm{http}: / / \mathrm{www} . c h i n a i n f o b a n k . c o m$. The distinction between provincial government and provincial people's congress is important, because the legislative authority of the former is more limited.

${ }^{23}$ The Liaoning SCE Measures refer in Art. 18 to the SCE's "legal person representative," a role that presumably can exist only in legal persons. Under the General Principles of Civil Law, legal persons have limited liability.

${ }^{24}$ 农业部, 农民股份合作企业暂行规定 [Ministry of Agriculture, Provisional Rules on Farmers' Shareholding Cooperative Enterprises] (Feb. 12, 1990), available at $\mathrm{http}: / / \mathrm{www}$.chinainfobank.com. ${ }^{25}$ See id. at art. 6.

${ }^{26}$ All-China Union of Light Industry, 轻工集体企业合作制试行办法 [Experimental Provisions on the Shareholding Cooperative System for Collective Enterprises in Light Industry] (Mar. 1, 1993), available at http://www.chinainfobank.com.

${ }^{27}$ State Commission on Reform of the Economic System, 关于发展城市股份合作制企业的指导意 见 [Guidance Opinion on the Development of Urban Shareholding Cooperative Enterprises] (Aug. 7, 1997), available at $\mathrm{http}: / / \mathrm{www} . c h i n a i n f o b a n k . c o m$.
} 
that SCEs are legal persons, and specifically provides that investors are not liable for the debts of the SCE beyond their capital contribution. ${ }^{28}$

Evidently branches of the State Administration of Industry and Commerce (the "SAIC") believe that existing statutory authority is good enough, as they are apparently registering such entities. As of the end of the year 2000, the SAIC had recorded the registration of almost 241,000 SCEs. $^{29}$

\section{Limited Liability Partnerships}

The Beijing Municipal People's Congress in 2000 issued the Regulations on the Zhongguancun Science and Technology Park (the "Zhongguancun Regulations"), which purport to allow the establishment of limited partnerships in the Zhongguancun district of Beijing. ${ }^{30}$ In a single article (Article 25), the Zhongguancun Regulations both allow for the creation of limited partnerships (有限合伙, youxian hehuo) and provide a single rule of governance and liability: "investors" shall be limited partners and shall not be liable for the debts of the partnership beyond their investment, and "asset managers" shall be ordinary partners, liable without limitation for all partnership debts. This single sentence was, at the time, the full extent of the governance and liability rules for limited partnerships then existing in China, although the Zhongguancun

\footnotetext{
${ }^{28}$ See id. at para. 4. Although it is an almost universal custom to state that shareholders in a limited liability company are liable for the debts of the company only to the extent of their capital contribution, this is in fact an inaccurate and misleading way of describing the situation. The shareholders are not liable at all. The capital contribution of original shareholders is irrelevant; as they transferred ownership of the contribution to the company, the assets in question belong to the company, not to the shareholders. True, they will never get their contribution back if the company goes bankrupt, but they are not entitled to get it back even if the company does not go bankrupt. All they are entitled to is a proportionate share of the company's assets after all debts have been paid. This might be greater or less than their contribution, but has nothing to do with its absolute amount. Shareholders who have bought shares on the secondary market have, of course, made no capital contribution at all, so the customary formula is even more misleading as applied to them.

${ }^{29}$ 国家工商行政管理局，中国2000年内资企业登记基本情况统计 [State Administration of Industry and Commerce, Statistics Showing the Basic Situation of Registered Domestic-Capital Enterprises in China in the Year 2000], in 中国工商行政管理年鉴 [YEARBOOK OF CHINESE INDUSTRIAL AND COMMERCIAL ADMINISTRATION 2001], available at http://www.chinainfobank. com. It is hard to know what to make of this figure, as another source reports the total number of SCEs one year earlier as 168,000. See 中国乡镇企业年鉴2000 [CHINA TOWNSHIP AND VILLAGE ENTERPRISE YEARBOOK] 186 (2000). Unless the number of SCEs leapt upward by $43 \%$ in a single year, both numbers cannot be right.

30 中关村科技园区条例 [Regulations on the Zhongguancun Science and Technology Park] (promulgated by the Beijing Municipal People's Cong., Dec. 13, 2000), available at http://www.chinainfobank.com.
} 
Regulations seem to treat limited partnerships as a well-understood and already-regulated business form.

The provisions of the Zhongguancun Regulations on limited partnerships were later supplemented by two more regulations issued by the Beijing municipal government (not the Municipal People's Congress). The first, the Measures for the Administration of Limited Partnerships, ${ }^{31}$ provide more by way of governance rules (including an unworkable rule that any disposition of partnership assets must have the unanimous approval of all the partners), and repeat the provision on limited liability. The second, the Measures on the Administration of Enterprise Registration in the Zhongguancun Science and Technology Park, ${ }^{32}$ contain instructions to the relevant local office of the $\mathrm{SAIC}^{33}$ (which is administratively under the Beijing government, not the central SAIC) to issue a business license in appropriate cases to limited partnerships, with the characters for "limited partnership" (有限合伙, youxian hehuo) printed on the certificate.

Let us consider what the Beijing Municipal People's Congress and government are doing. The point, among others, of a law or regulation providing for limited partnerships is to limit the liability of certain partners in cases where, absent the law or regulation, they would be liable. This liability, in China, would be imposed by virtue of laws passed by various bodies, including the National People's Congress. Probably few Chinese legal scholars would agree that the Beijing Municipal People's Congress or the city government has the power to nullify creditor's rights arising under national law. Yet this is exactly what the limited partnership regulations purport to do. Moreover, they instruct the local AIC to create a category of enterprise not sanctioned by national law, and one that is governed by a norm specifically rejected by national law: the Partnership Law states that all partners, not just some, shall be liable for the debts of the partnership. ${ }^{34}$

Whether the Beijing AIC, whose officials are appointed and salaried by the Beijing government, should obey this instruction is an interesting theoretical question; that they will in fact obey this instruction seems beyond question. The interesting issue is what a Chinese court or

\footnotetext{
${ }^{31}$ Beijing Municipal Government, 有限合伙管理办法 [Measures for the Administration of Limited Partnerships] (Feb. 21, 2001), available at http://www.chinainfobank.com.

${ }^{32}$ Beijing Municipal Government, 中关村科技园区企业登记注册管理办法 [Measures on the Administration of Enterprise Registration in the Zhongguancun Science and Technology Park] (Mar. 2, 2001), available at $\mathrm{http}: / / \mathrm{www} . c h i n a i n f o b a n k . c o m$.

${ }^{33}$ Such local counterparts of the SAIC will hereinafter be referred to as "AICs."

${ }^{34}$ 中华人民共和国合伙企业法 [Partnership Law] art. 5 (promulgated by the Standing Comm. of the Nat'l People's Cong., Feb. 23, 1997, effective Aug. 1, 1997) 03/01/1997 全国人民代表大会常务委 员会公报 [STANDING COMM. NAT'L PEOPLE'S CONG. GAZ.] 1 (P.R.C.) (“A partnership may not use the words 'limited' or 'limited liability' in its name."); see also id. at art. 8 ("There [must be] two or more partners, all of whom shall bear unlimited liability in accordance with law.").
} 
governmental authority not under the jurisdiction of the Beijing government will do when faced with an assertion of the limited partnership's existence. Specifically, suppose a creditor of the partnership wishes to join a "limited partner" as a defendant in a lawsuit, and suppose further that neither the creditor nor the court hearing the suit is in Beijing. Will it—should it-recognize the limited partner's claim of immunity from liability? To do so would be to allow the Beijing government to strip non-Beijing residents of rights granted to them under national law. ${ }^{35}$ It should also be noted that the rules on governance, to the extent they exist at all, exist largely as a regulation of the Beijing municipal government. Such a regulation ranks very low in the formal legislative hierarchy.

\section{Limited Liability Companies and Joint Stock Companies}

Before the Company Law became effective in 1994, there was no basis for LLCs or joint JSCs in laws (法律, falü) or administrative regulations (行政法规, xingzheng fagui). The only normative basis for the existence of such entities lay in departmental regulations (部门规章, bumen guizhang): the Standard Opinion on Limited Liability Companies ${ }^{36}$ and the Standard Opinion on Joint Stock Companies, ${ }^{37}$ both issued by SCRES, a commission under the State Council, on May 15, 1992. Yet it is clear that courts and administrative bodies around the country acknowledged both the existence of LLCs and JSCs organized under the Standard Opinions and the limited liability of their investors.

\footnotetext{
${ }^{35}$ This would not be the first time such an event had occurred. Examples of the same thing can be found in local bankruptcy regulations promulgated in the mid-1980s by the city governments of Shenyang, Wuhan, and Chongqing. See Bankruptcy Law Proves Successful, CHINA DAILY, June 24, 1986, at 3; see also 企业破产制逐步建立; 沈阳, 武汉, 重庆做试点 [The Enterprise Bankruptcy System Is Gradually Established; Shenyang, Wuhan, and Chongqing Are Trial Areas], 大公报 [DA GONG BAO] (H.K.), June 22, 1986, at 3. Such regulations purported to adjust the rights of creditors of the bankrupt enterprise, even where such creditors were beyond the jurisdiction of the city government in question. I have analyzed early bankruptcy principles, and the Shenyang regulations in particular, in It Don't Mean a Thing If It Ain't Got That Sting: The Theory and Law of Bankruptcy in China (Dec. 5, 1986) (unpublished manuscript).

${ }^{36}$ State Commission on Reform of the Economic System, 有限责任公司规范意见 [Standard Opinion on Limited Liability Companies] (May 15, 1992), available at http://www.chinainfobank. com.

${ }^{37}$ State Commission on Reform of the Economic System, 股份有限公司规范意见 [Standard Opinion on Joint Stock Companies] (May 15, 1992), available at http://www.chinainfobank.com.
} 


\section{E. State-Owned Enterprises}

Finally, we come to one of the most interesting cases of all: the state-owned enterprise ("SOE") in its traditional form. Although the People's Republic of China has had state-owned enterprises since the earliest years of its existence, there was, remarkably enough, no organic statute governing such enterprises - certainly not at the national level, at any rate-until 1988, when the National People's Congress passed the Law on Industrial Enterprises Owned by the Whole People (the "SOE Law"). ${ }^{38}$ Article 2 of the SOE Law spells out that SOEs are legal persons, and the SOE debts are paid only out of assets managed by the SOE. Yet this was clearly the understanding well prior to the passage of the SOE Law, indeed as far back as the $1950 \mathrm{~s},{ }^{39}$ and there can be absolutely no doubt that some well understood (although non-statutory) method existed for identifying what kinds of organizations counted as SOEs and what kinds did not, and that that method worked most of the time in a straightforward way.

\section{ANALYSIS}

The basic problem can be simply stated. If Zhang and Wang, two individuals, draw up a document stating that they have created an organization with limited liability, and then go into business and sign all their contracts with creditors in the name of the organization, it will be of no avail to them if their creditors seek to make them personally liable for the debts they have incurred in the course of doing business. The courts will (rightly) note that individuals do not have the power to create limited liability for themselves. Even if they were to argue successfully that their creditors had implicitly agreed not to seek their personal liability, a court would still allow their personal creditors to seize assets used in the

\footnotetext{
${ }^{38}$ See generally 中华人民共和国全民所有制工业企业法 [Law on Industrial Enterprises Owned by the Whole People] (promulgated by the Nat'l People's Cong., Apr. 13, 1988, effective Aug. 1, 1988) (P.R.C.), available at http://www.molss.gov.cn/correlate/qmgyqyF.htm (last visited Feb. 21, 2006).

${ }^{39}$ A well-known 1958 textbook on civil law states not only that the SOEs are legal persons, but that their debts may be satisfied only out of their circulating capital and not out of fixed assets. See Central Political-Legal Cadres School, Civil Law Teaching and Research Division, 中华人民共和国民法基 本问题 [Basic Problems in the Civil Law of the People's Republic of China] 138-39 (1958). Neither of these propositions had, to my knowledge, any statutory basis at the time this textbook was written, yet both seem to have been accepted as common knowledge. Indeed, the latter proposition is so deep-rooted that it was cited to me by a Chinese lawyer in 1992 ("Normally, one doesn't execute against means of production; one executes against circulating funds.") despite its continuing lack of statutory basis. See Donald C. Clarke, Power and Politics in the Chinese Court System: The Enforcement of Civil Judgments, 10 COLUM. J. ASIAN L. 1 (1996).
} 
business, something it should not do for a business with recognized legal personality. ${ }^{40}$

On the other hand, if the National People's Congress or its Standing Committee says, through legislation, that the organization created by Zhang and Wang has legal personality, courts and other government agencies will recognize and acknowledge the existence of the organization and implement various rules regarding limited liability, separation of business assets from personal assets, etc.

What about intermediate organizations? Will courts and government agencies recognize an organization whose purported legal personality and limited liability is grounded in a document issued by a villagers' committee? One suspects they would not. What about a township government? If we start from the top, it seems clear that courts and government agencies recognize legal personality grounded in a document issued by the State Council or a central government ministry, but how much lower can we go, and what is the principle governing recognition?

There are two possible approaches to this question. The first is to assume that a rule, written or unwritten, exists that governs this issue. One would find the rule by canvassing all available materials with the aim of finding in them, if not a clearly articulated statement of a rule, at least a reasonably consistent pattern of behavior from which we would deduce the existence of an unwritten or customary rule. To find such an unwritten rule, it is not necessary to find that behavior always conforms to it; indeed, it must be possible, and meaningful, to criticize behavior as not conforming to it. A rule that explained every decision would not be realistic, since it would involve an assumption that decision-makers never made mistakes. This approach is - or at least was, before the advent of modern critical approaches - the meat and potatoes of the legal scholar in common law jurisdictions.

In this essay I want to call attention to the possibility of another approach: to postulate that the very attempt to find a consistent rule involves a misunderstanding of what the system is all about; that the system under examination is not designed to produce consistent rules, and that any rationalization of existing decisions is not the discovery of an inherent underlying principle, but rather nothing more than a formulation

\footnotetext{
${ }^{40}$ A court would instead allow their personal creditors to seize their ownership interest in the business. Because they can then liquidate the business and distribute the assets to themselves, one might think there was no substantial difference. But when a creditor takes an ownership interest, it steps into the shoes of the owners, and must wait in line behind the business's creditors before it can liquidate the business for its own benefit.
} 
that happens to fit the materials today but may not fit them tomorrow. In other words, I want to postulate that there simply does not exist any consistent rule of recognition guiding the decisions of various governmental agencies in China when they face the question of whether or not to acknowledge a claim that a particular business entity "exists" and that particular consequences should follow from the existence. While such a consistent rule might be a good idea, there is nothing in the Chinese legal system that will operate to produce one.

This claim follows from what I posit as a fundamental characteristic of China's current legal system: its radical polycentricity. In calling the Chinese legal system polycentric, I mean to say that, as a practical matter, there is no single source of ultimate authority in the system. Indeed, to make this claim might be the equivalent of saying that there is no single Chinese legal "system," 41 that there are instead many Chinese legal systems, each with its own jurisdiction, hierarchy of authority, and way of operating.

This claim should not be understood as a denial that polycentricity exists in greater or lesser degrees in other systems, or as a claim that thorough and complete monocentricity - in which there existed a single, readily identifiable, and never ambiguous authoritative pronouncer on legal matters - could even exist in principle. It is, however, a claim that polycentricity in China is different enough from polycentricity in other societies so as to be worth exploring. In particular, polycentricity in China is different because unlike the polycentricity usually observed by legal anthropologists, in which state legal norms co-exist and compete with norms from other sources, the legal polycentricity I observe and discuss here exists entirely within the state apparatus, despite the formal subordination of its various sources to a single authority.

To understand the claim of this essay, it is important to understand the role of law in modern Chinese society generally and its relationship to the state bureaucracy. Law in China is distinctly subordinate to the state bureaucracy. To forestall misunderstanding, let me be clear that this statement is made not to criticize, but to explain. Let us imagine two opposite models of the relationship between the state bureaucracy and the law. One may be called the "rule of law" model. In this model, a particular state agency exists pursuant to law and derives its powers from legal enactments. Its actions are judged, among other criteria, by whether or not they are within its lawfully defined scope of authority. Although it is possible for a state agency to act unlawfully, it can be meaningfully

\footnotetext{
${ }^{41}$ I understand Stanley Lubman to be saying much the same thing in his book Bird in a Cage. See generally STANLEY B. LUBMAN, BIRD IN A CAGE: LEGAL REFORM IN CHINA AFTER MAO 3 (1999).
} 
criticized for doing so, and there are accepted parameters within which to carry out that criticism and defense. The agency would defend its actions on the grounds of lawfulness, not on the grounds that law was irrelevant. In short, all actors acknowledge a concept of legitimacy, and while disagreements are obviously possible, there exists an institutional mechanism and a forum for settling those disagreements.

The opposite model may be called the "practical power" model. In this model, a particular state agency exists because it has been established by superior political authorities. It does not need a legal basis any more than the Chevrolet division of General Motors needs a legal basis. The existence of this agency and the scope of its powers may well be the subject of political negotiations, just as with agencies that owe their existence to legislation, but unlike agencies in the rule of law model, they are not subject to a concept of legitimacy. More importantly, there is no unified institutional mechanism and forum for resolving disagreements about the proper scope of an agency's power. An agency's powers are defined less by a concept of what it has a right to do than by what it has the actual capacity to do.

Let me stress that these models are intended as ideal types, not as actual descriptions of the way the system of any particular country or society works. I offer them as ways of usefully thinking about, comparing, and evaluating different real-world systems. While reality is too complex to be accurately described by a model, it is at the same time true that reality can only be described by a model; since the number of facts about the universe is limited only by our imagination, any description must inherently be selective and interpretive. My claim is that the practical power model offers a better lens than the rule of law model through which to understand the relationship of law to government bureaucracy in China: "better" in the sense that fewer observations have to be explained as deviant. If one assesses the powers of Chinese government agencies using the rule of law model, one can only conclude - as many have-that the situation is by and large a mess. If one assesses their powers using the practical power model, much more of what we see makes sense.

The practical power model offers a useful way of approaching the puzzle posed at the beginning of this essay. Here I will outline some general principles in its application to Chinese enterprise law.

First, the study of large Chinese business organizations is-at least at present-primarily the study of the activity of governmental and quasi-governmental bodies in the realm of industry and commerce. This is why such a study must be founded on an understanding of how Chinese government agencies operate. The practical power model suggests that 
attempting to understand large Chinese business organizations by looking at enterprise law is as useful as attempting to understand the internal organization of General Motors by looking at Delaware corporate law.

Second, the legal rules that do exist are primarily regulatory, not enabling. It is not the primary purpose of the rules to facilitate activity and organization that might not otherwise take place, or to create organizations. Instead, their primary purpose is to regulate activity and organizations already in existence, or at least not owing their existence to the rules. The legally recognized existence of a business organization is seen as a matter of social and political fact, not one of legal definition.

Third, enterprise regulation is fragmented and strongly sector-oriented. Because enterprises can be created by numerous parallel government agencies none of which have jurisdiction over the other (for example, ministries under the State Council), it follows that no single body, unless of superior bureaucratic rank, can have jurisdiction over all enterprises for the purposes of its particular mission. There are a few agencies that might seem to be exceptions to this principle. The State Administration of Industry and Commerce has authority over enterprise registration and certain other aspects of company regulation. But it is not clear how much power it really has against a state-owned enterprise under a powerful ministry. ${ }^{42}$ The same goes for the State Administration of Environmental Protection and its local branches; both they and the enterprises they regulate have a certain rank, and they have very little power to impose their will on enterprises of equal or higher rank. ${ }^{43}$ The one real exception to this principle is the China Securities Regulatory Commission, which seems to have genuine authority, at least to some degree, over a certain class of enterprises regardless of sector or rank: companies that issue publicly listed shares.

\footnotetext{
${ }^{42}$ Indeed, the terminally indeterminate nature of the powers of various government organizations is probably the reason for the puzzling silence of the Company Law in Chapter 10, when it deals with sanctions to be imposed on companies and their officers for various transgressions, regarding just who has the power to impose the sanctions. It is possible in Chinese-although hardly good drafting in a legal document-to have an active verb without any specified subject, and Article 216 is a good example of the result: "When a company does not make a set-aside for the public accumulation fund and public welfare fund in accordance with the provisions of this Law, [subject omitted] shall order it to supplement the amount it should have set aside, and may also impose on the company a fine of from $¥ 10,000$ to $¥ 100,000$." We are not told who is to do the ordering and the imposing. Since an offending company might be under the direct administrative control of a government department with a rank equal to or higher than that of any agency that might be in a position to impose a punishment (for example, the SAIC), the identity of the punishment imposer had to be left unstated.

${ }^{43}$ See, for example, the case discussed in Xiaoying Ma \& Leonard Ortolano, ENVIRONMENTAL REGULATION IN CHINA: INSTITUTIONS, ENFORCEMENT, AND COMPLIANCE 81 (2000), in which an enterprise under provincial jurisdiction refused to recognize the authority of a municipal environmental protection bureau to regulate it.
} 
As a result, Chinese enterprise law is only a part of what there is to say about Chinese enterprise organization and the practical rights of various claimants to enterprise assets: investors, creditors, managers, workers, customers, tort victims, and others. Indeed, it follows as a natural consequence of the practical power model that legal sanction is not necessary for a Chinese enterprise to have a valid legal existence, by which I mean an existence that is acknowledged as affecting legal rights of various parties. An enterprise can "exist" if a government agency says it exists and has the capacity to make its fiat respected in part or all of the system. There are no rules about which government agency has the power to create what kind of enterprise, and there is no settled way to resolve disputes about such power.

Thus, there is simply no systematic way to answer the question of when a claim that a particular business entity exists will be recognized and acknowledged. We have to ask whether a particular corporate form will be recognized by a particular government agency for a particular purpose. This may result in conflicting answers, depending on the situation, because there is no universally recognized source of authority for the recognition of entity status.

Developments in the last few years have provided an unusually sharp example of this problem. In 2002, the China Securities Regulatory Commission ("CSRC") announced that it would approve foreign-invested LLCs in the business of fund management ${ }^{44}$ as well as securities. ${ }^{45}$ If one attempts to use the customary techniques of legal analysis to understand whether the CSRC has the authority to bring foreign-invested fund management companies (in the LLC form) into existence, one quickly becomes bogged down in hopeless confusion. The traditional rule-or perhaps one should say practice-with respect to all foreign investment has been that the approval of the Ministry of Foreign Trade and Economic Cooperation ("MOFTEC") (or its successor, the Ministry of Commerce) is required, and that therefore compliance with various MOFTEC policies and regulations was necessary-at least unless MOFTEC or some body superior to MOFTEC, such as the State Council or the National People's

\footnotetext{
${ }^{44}$ 中国证券监督管理委员会, 外资参股基金管理公司设立规则 [China Securities Regulatory Commission, Rules on the Establishment of Fund Management Companies with Foreign Shareholding] (issued June 1, 2002, effective July 1, 2002), available at http://www.chinainfobank. com.

${ }^{45}$ 中国证券监督管理委员会，外资参股证券公司设立规则 [China Securities Regulatory Commission, Rules on the Establishment of Securities Companies with Foreign Shareholding] (issued June 1, 2002, effective July 1, 2002), available at http://www.chinainfobank.com.
} 
Congress, said otherwise. ${ }^{46}$ These policies and regulations have so far not made any provision for foreign investment in LLCs under the Company Law.

The first question, therefore, is precisely what kind of company, under what statutory authority, is called for by (for example) the Securities Company Rules. The Rules stipulate in Article 4 that a foreign-invested securities company (a "FISC") approved under the Rules shall take the form of a limited liability company (有限责任公司, youxian zeren gongsi). But does this mean an LLC solely under the Company Law, or does it mean a company with limited liability that is organized under one of the statutes governing entities with foreign investment, that is, the Equity Joint Venture Law, the Cooperative Joint Venture Law, or the Law on Wholly Foreign-Owned Enterprises (a "standard FIE")? It is not the case that the only permissible vehicles for foreign investment are standard FIEs - JSCs with foreign investment, for example, are allowed by MOFTEC and generally recognized as validly existing-but it is true that for standard FIEs, the approval of MOFTEC or its local government counterpart is necessary. This is spelled out not only in the Equity Joint Venture Law (Article 3), the Cooperative Joint Venture Law (Article 5), and the Law on Wholly Foreign-Owned Enterprises (Article 6), but also in the State Council's Guidance Rules for Foreign Investment (the "Guidance Rules"). ${ }^{47}$

If the FISC is a standard FIE, then, it would seem that MOFTEC approval would, under statutory law and State Council regulations, be necessary. Yet MOFTEC's own position on this issue has been ambiguous. On the one hand, a senior MOFTEC official is on record as expressing MOFTEC's official view that FISCs are Chinese-foreign equity joint

\footnotetext{
${ }^{46}$ It is the role of the State Council that makes a previous transfer of foreign investment approval power to the China Insurance Regulatory Commission (the "CISC") different from the CSRC's assertion of jurisdiction. The Regulations on the Administration of Insurance Companies with Foreign Investment, which became effective in February of 2002, do indeed give the CISC the sole right to approve the establishment of foreign-invested enterprises in the insurance industry. See 中华 人民共和国外资保险公司管理条例 [Regulations on the Administration of Insurance Companies with Foreign Investment] (promulgated by the State Council, Dec. 12, 2001, effective Feb. 1, 2002), available at http://www.chinainfobank.com. But the regulations were issued by the State Council, which stands above both the CISC and MOFTEC.

${ }^{47}$ 指导外商投资方向规定 [Rules for the Guidance of the Direction of Foreign Investment] (promulgated by the State Council, Feb. 11, 2002, effective Apr. 1, 2002), available at http://www.chinainfobank.com. Article 2 of the Guidance Rules defines "foreign-invested enterprise" to mean an equity joint venture, a cooperative joint venture, or a wholly foreign-owned enterprise (presumably in each case established under the applicable law). Article 12 then states that the contract and articles of association of a foreign-invested enterprise must be approved by MOFTEC or its local government counterpart.
} 
ventures, ${ }^{48}$ and therefore presumably subject to the rules of the Equity Joint Venture Law requiring MOFTEC approval. On the other hand, the same official is also on record describing an approval process for FISCs in which MOFTEC has no role whatsoever ${ }^{49}$ (in other words, agreeing that CSRC approval alone is sufficient).

If a FISC is not a standard FIE, then the term "limited liability company" in Article 4 of the Securities Company Rules must mean an LLC authorized and governed solely by the Company Law. But if this is so, why is CSRC approval needed at all for the FISC to exist? There is no requirement in the Company Law that LLCs receive the approval of some government ministry before they may be registered by the local AIC. There is arguably a requirement that any person or organization intending to operate a securities business must have CSRC approval to do so, but this is not a Company Law issue; the requirement would apply equally to individuals, rural collectively-owned enterprises, partnerships, etc. There is no logical reason why an LLC cannot be established before it has received permission to conduct business in its chosen area, and indeed the local AIC would not be able to find in the Company Law, or in any other law, a basis for denying registration to an LLC simply because one of the investors was a foreign entity. A local AIC might argue that there is no law specifically permitting such an entity, but this argument fails for two reasons. First, there is no law specifically permitting LLCs with any number of characteristics, including investors who live in Shanghai or are surnamed Zhang, and yet this is not a bar to their registration. Second, a CSRC document does not rise to the level of a norm binding on the SAIC and its local counterparts, and so the CSRC's assertion of the right to decide whether an LLC may be registered need not be respected by the AIC.

Thus, while CSRC approval can be viewed as necessary in order for any person or entity, including of course LLCs with foreign investment, to engage in the securities business, once the need for MOFTEC approval of business entities with foreign investment is no longer universally acknowledged, then it is hard to see why any approval by any government body should be necessary for LLCs or JSCs with foreign investment at

\footnotetext{
${ }^{48}$ See 外资导向系列:外资参股证券包括股票债券 [Foreign Investment Guidance Series: [The Scope of Business of] Securities [Companies] with Foreign Shareholding Includes Stock and Bond [Operations]], 文汇报 [WEN HUI BAO] (H.K.) (July 9, 2002), available at http://www.chinainfobank. com (quoting Hu Jingyan, head of MOFTEC's Department of Foreign Capital (外资司, waizi si)). ${ }^{49} \mathrm{See}$ 外资导向系列: 外资参股证券公司手续 [Foreign Investment Guidance Series: Procedures for Securities Companies with Foreign Shareholding] 文汇报 [WEN HUI BAO] (H.K.) (July 11, 2002), available at $\mathrm{http}: / / \mathrm{www}$.chinainfobank.
} 
least to be registered by local AICs, even if they may not lawfully do business in their intended field.

Interestingly, there is one highly authoritative rule on the approval question that does in fact supply something of an answer, but that seems to have been ignored by the CSRC, MOFTEC, and commentators. I have noted above ${ }^{50}$ that the State Council's 2002 Guidance Rules on Foreign Investment call for approval by MOFTEC of any standard FIE. But the Guidance Rules also define foreign investment in vehicles other than standard FIEs; they use the term “foreign-invested projects" (外商投资项 目, waishang touzi xiangmu) (Article 2). And they go on to state in Article 12 that foreign-invested projects - all forms of foreign investment that do not fall into one of the standard FIE forms - "shall be examined and approved and filed by the development and planning departments and the economic and trade departments respectively on the basis of the nature of the projects." If the FISC is not a standard FIE, in other words, it still must be approved by more than just the CSRC; it must also be approved by the State Development Planning Commission or the State Economic and Trade Commission (or the local counterpart of either). And yet this apparent State Council requirement does not appear anywhere in the Securities Company Rules. Did it in fact become a dead letter only months after its enactment? Can the CSRC really override the State Council? Will departments of tax, customs, and immigration recognize the existence of the CSRC-approved entity without the approvals called for by Article 12 of the Guidance Rules on Foreign Investment?

The point of the above exercise is to suggest that these questions are, in a legal sense, really unanswerable. Of course, as a legal matter, the CSRC does not have the legal right to override a State Council rule. As the chief of the CSRC is appointed by the Premier, who heads the State Council, there is no reason to think the CSRC as a body would deliberately flout the wishes of the State Council.

Will local AICs, having read this essay and realized their "mistake" now start approving foreign-invested LLCs without requiring further approvals from line ministries? It seems unlikely, and so far has not happened. In all these cases, however, the guide to the actions of the various government ministries whose acknowledgment is necessary for an enterprise to achieve its full existence cannot meaningfully be said to be legal. The tools of the political scientist or perhaps the sociologist are far more appropriate to the task of answering the question posed at the

${ }^{50}$ See id. 
beginning of this essay: On what basis does a government agency decide that a business entity does or does not exist?

\section{CONCLUSION}

The issue canvassed here underscores the importance, in any realistic analysis of the Chinese legal system, of taking polycentrism into account. For many issues, there is simply no single institution that has the authority, the power, and the desire to have the last word. As a result, what appears at times to be a kind of anarchy in the system, where government agencies do not follow the law, is perhaps better explained as a kind of hyperarchy, where there are too many legal authorities, each empowered to make law for as far as it has the power to stretch its jurisdiction, and there exists no institution capable of discovering and reducing inconsistencies.

How, and indeed whether, this area of enterprise law can be reformed is indeed a puzzle. More and better National People's Congress legislation is not the solution, because part of the problem is that NPC legislation is not recognized by courts and government agencies as the sole legitimate source of corporate existence. The current state of affairs is likely to continue until political changes occur that reduce the number of centers of legal power. 